\title{
Political Branding Tagar \#2019gantipresiden Dalam Meningkatkan Elektabilitas Partai Keadilan Sejahtera Di Ranah Media Sosial ${ }^{*}$
}

\author{
Ridwan Rachmadi, ${ }^{1}$ Heri Budianto ${ }^{2}$ \\ Universitas Mercu Buana \\ do \\ 10.15408/sjsbs.v7i11.17057
}

\begin{abstract}
The hashtag \#2019GantiPresiden was initiated by Dr. Mardani Ali Sera, a politician from the Partai Keadilan Sejahtera (PKS) has become a trending topic on social media, the use of hashtags has increasingly colored political dynamics in the country's public sphere. The research aims to obtain an overview of the Political Branding of the \#2019GantiPresiden hashtag in increasing the electability of the Partai Keadilan Sejahtera in the realm of social media. This research uses a constructivist paradigm, a qualitative approach and a case study method. The results showed that the Partai Keadilan Sejahtera was able to make good use of social media as a campaign tool and was able to present its best politician to become national figures. One of them was Dr. Mardani Ali Sera who initiated the hashtag \#2019GantiPresiden. The hashtag \#2019GantiPresiden became a trending topic, the surface was present ahead of the 2019 Presidential election which presented only two candidates for the Presidential and Vice-Presidential candidate pairs. The public's desire for a replacement of the President is accommodated through the hashtag \#2019GantiPresiden. The hashtag \#2019GantiPresiden is affiliated with one of the Presidential Candidates and Vice-Presidential Candidates carried by the Prosperous Justice Party. The hashtag \# 2019ChangePresident benefits the Prosperous Justice Party because it is a cadre of the Prosperous Justice Party who initiated it. Political Branding Tagar \# 2019GantiPresiden contributes to increasing the electability of the Prosperous Justice Party in the realm of social media so that it has implications for the vote results obtained by the Prosperous Justice Party in the 2019 legislative elections.
\end{abstract}

Keywords: Political Branding, Tagar, 2019 Change President, Prosperous Justice Party, Social Media

\begin{abstract}
Abstrak
Tanda pagar \#2019GantiPresiden di inisiasi Oleh Dr. H. Mardani Ali Sera, M. Eng., politikus PKS (Partai Keadilan Sejahtera) telah tranding topik di media sosial penggunaan tanda pagar (tagar) mewarnai dinamika politik di ruang publik tanah air. Penelitian bertujuan untuk memperoleh gambaran tentang political branding tagar \#2019GantiPresiden dalam meningkatkan elektabilitas Partai Keadilan Sejahtera di ranah media sosial. Penelitian menggunakan paradigma konstruktivis, pendekatan kualitatif dan metode studi kasus. Hasil penelitian menggambarkan bahwa, Partai Keadilan Sejahtera mampu memanfaatkan media sosial sebagai sarana kampanye dengan baik dan mampu menghadirkan kader-kader terbaiknya menjadi tokoh nasional salah satu diantaranya adalah Dr. H. Mardani Ali Sera, M. Eng yang menginisiasi tagar \#2019GantiPresiden. Tagar \#2019GantiPresiden menjadi tranding topik, hadir kepermukaan jelang perhelatan pemilu Presiden 2019 yang menghadirkan hanya ada dua pasang kandidat calon Presiden dan Wakil Presiden.
\end{abstract}

* Received: July 16, 2020, Revision: July 17, 2020, Published: December 5, 2020.

${ }^{1}$ Ridwan Rachmadi adalah Peneliti pada Program Studi Magister Ilmu Komunikasi, Program Pasca Sarjana Universitas Mercu Buana. Email: ridwan.rachmadi@gmail.com.

${ }^{2}$ Heri Budianto adalah Peneliti pada Program Studi Magister Ilmu Komunikasi, Program Pasca Sarjana Universitas Mercu Buana. Email: herbudmkom@gmail.com. 
Keinginan masyarakat akan pergantian Presiden terakomodir melalui tagar \#2019gantiPresdien. Tagar \#2019GantiPresdien berafiliasi dengan salah satu kandidat Calon Presiden dan Calon Wakil Presiden yang di usung oleh Partai Keadilan Sejahtera. Tagar \#2019GantiPresiden menguntungkan Partai Keadilan Sejahtera karena yang menginisiasinya adalah kader Partai Keadilan Sejahtera. Political Branding Tagar \#2019GantiPresiden berkontribusi menaikan elektabiltas Partai Keadilan Sejatera di ranah media sosial sehingga berimplikasi pada hasil suara yang di dapat oleh Partai Keadilan Sejahtera pada pemilu legislatif tahun 2019.

Kata Kunci: Political Branding, Tagar, 2019 Ganti Presiden, Partai Keadilan Sejahtera, Media Sosial

\section{A. PENDAHULUAN}

Tanda pagar \#2019GantiPresiden yang diinisiasi oleh Mardani Ali Sera putra asli kelahiran Jakarta ini semakin masif digaungkan menjelang Pemilihan Presiden atau Pilpres 2019. Setelah dikukuhkan sebagai sebuah gerakan masyarakat pada 6 Mei 2018, penggunaan tagar itu kian mewarnai dinamika politik di ruang publik tanah air. Dalam pemilihan langsung kepala daerah provinsi Jawa Barat tahun 2018 misalnya, pasangan Asyik (Sudrajat-Syaikhu) yang diusung oleh Patai Gerindra, PKS, dan PAN menggunakan tagar itu untuk membantu mendongkrak popularitas dan elektabilitas. Pada penghujung acara debat di Balairung Universitas Indonesia, Depok, 14 Mei 2018, keduanya membentangkan kaus bertuliskan "2018 Asyik menang, 2019 ganti presiden". Cara "Asyik" meningkatkan keterpilihannya di Jabar dengan cara "mendompleng" tagar itu diakui pula oleh rivalnya, Dedi Mulyadi3 ${ }^{3}$. Timses Asyik disebut mengampanyekan tagar itu melalui selebaran, paket, dan sebagainya secara merata di permukiman Jabar hingga suara Deddy Mizwar-Dedi Mulyadi tergerus.

Perkembangan media baru semakin pesat dan tidak bisa terlepas dari pesatnya perkembangan teknologi dan globalisasi. Internet sebagai dasar media baru menghasilkan berbagai media sosial yang banyak diterima dengan baik oleh kebanyakan masyarakat luas di Indonesia. Hal ini dibuktikan dengan data yang tersajikan bahwa pengguna internet di Indonesia per tahun 2014 yang dirilis oleh Asosiasi Penyelenggara Jasa Internet mencapai 88,1 juta orang dan dari jumlah tersebut 63 juta orang Indonesia memiliki media sosial. Menurut Gunelius media sosial adalah penerbitan online dan alat-alat komunikasi, situs, dan tujuan dari Web yang berakar pada percakapan, keterlibatan, dan partisipasi.

Sebagian ahli sampai pada kesimpulan bahwa media baru membawa efek yang berarti kepada perkembangan demokrasi di Indonesia. Asumsinya adalah, para teoretis demokrasi selama ini percaya bahwa demokrasi dapat terjaga dan terawat adalah karena ada partisipasi politik dari warga negara yang aktif dan peduli terhadap masalah-masalah warga masyarakat (civic affairs). Disamping itu, dalam pandangan Terri L. Towner ${ }^{4}$ (2013:528) penggunaan media massa merupakan prediktor positif ( $a$ positive predictor) dari partisipasi politik, dan sebagaimana peta media telah berubah,

\footnotetext{
3https://nasional.republika.co.id/berita/nasional/pilkada/pb87ny354/dedi-mulyadi-nilai-tagar2019gantipresiden-gerus-suaranya

${ }^{4}$ Towner, Terri L. (2013). All Political Participation Is Socially Networked? New Media and the 2012 Election. Social Science Computer Review.
} 
internet telah memainkan peran yang semakin besar dan penting dalam politik. Sebagian pengamat membesarkan peran internet sebagai alat yang dapat membantu proses demokrasi dengan memberikan ekspos kepada warga masyarakat terhadap informasi politik.

Menurut pandangan Towner, hubungan antara penggunaan Internet dan tingkat partisipasi masih menjadi perdebatan di kalangan para ahli. Beberapa ahli berpendapat bahwa penggunaan internet memiliki pengaruh positif terhadap partisipasi politik, pengetahuan dan keterlibatan warga (knowledge and civic engagement) melalui modal sosial, sementara sebagian lain berpendapat bahwa penggunaan internet kecil dampaknya dan tidak berefek pada partisipasi politik.

Penelitian ini dimaksudkan sebagai konsep penerapan fungsi Ilmu Komunikasi yang dilaksanakan dengan tujuan untuk mengetahui Political Branding Tagar \#2019GantiPresiden dalam Menaikan Eelektabilitas Partai Keadilan Sejahtera di Ranah Media Sosial. Dari latar belakang dan rumusan masalah di atas, maka peneliti dapat menjelaskan tujuan penelitian sebagai berikut: Mendeskripsikan Political Branding Tagar \#2019GantiPresiden dalam Menaikan Elektabilitas Partai Keadilan Sejahtera di Ranah Media Sosial

\section{B. METODE PENELITIAN}

Menurut Patton (2002:69, ${ }^{5}$ paradigma adalah cara pandang pada dunia (worldview), yaitu sebuah cara berpikir dan memahami kompleksitas dari dunia nyata. Paradigma menjelaskan mengenai hal apa yang menjadi penting, memiliki legitimasi, dan masuk akal. Paradigma juga bersifat normatif dengan memberitahu praktisi tentang hal yang harus dilakukan tanpa perlu memikirkan banyak pertimbangan eksistensial atau epistemologis.

Penelitian ini menggunakan paradigma konstruktivis dengan pendekatan kualitatif. Dimana paradigma adalah suatu cara pandang untuk memahami kompleksitas dunia nyata. Paradigma tertanam kuat dalam sosialisasi para penganut dan praktisinya. Paradigma menunjukan pada mereka apa yang penting, absah, dan masuk akal. Paradigma juga bersifat normatif, menunjukkan kepada praktisinya apa yang harus dilakukan tanpa perlu melakukan pertimbangan eksistensial atau epsitemologis yang panjang. ${ }^{6}$

Dalam penelitian ini peneliti menggunakan pendekatan kualitatif, dan lebih mengggunakan paradigma konstruktivis yang memang mendekati pada kasus yang sedang menjadi fenomena di Indonesia jelang Pemilu 2019. Penelitian ini di konsep sebagai penelitian studi kasus, penelitian studi kasus adalah suatu penelitian kualitatif yang berusaha menemukan makna, menyelidiki proses, dan memperoleh pengertian dan pemahaman yang mendasari individu, kelompok, atau situasi. Menurut Smith,

${ }^{5}$ Patton, Micheal Quinn. 2002. Qualitative Research and Evaluation Methods. USA: Sage Publication,

Inc

\footnotetext{
${ }^{6}$ Deddy Mulyana, Metodologi Penelitian Kualitatif. (Bandung: PT Remaja Rosdakarya, 2006)
} 
studi kasus dapat menjadi berbeda dari bentuk-bentuk penelitian kualitatif lain oleh fakta bahwa studi ini berfokus pada satu unit tanggal atau sistem terbatas. ${ }^{7}$

Kasus yang dibahas dalam penelitian ini adalah Political Branding Tagar \#2019GantiPresiden Dalam Meningkatkan Elektabilitas Partai Keadilan Sejahtera dengan tagar \#2019GantiPresiden sebagai kata kunci utama dalam penelitian ini.

Penelitian studi kasus adalah penelitian yang meneliti fenomena secara utuh dan menyeluruh dalam paket yang lengkap (all package) pada kondisi yang sebenarnya, dengan menggunakan berbagai bentuk data kualitatif. Karakteristik penelitian studi kasus pada umumnya sama dengan karakteristik, penelitian kualitatif yaitu menggali substansi mendasar di balik fakta yang terjadi di dunia. Lebih lanjut, K. Yin menerangkan bahwa studi kasus memungkinkan peneliti untuk mempertahankan karakteristik holistik (menyeluruh) dan bermakna dari peristiwa-peristiwa kehidupan nyata. Penjelasan ini menjadi dasar pijakan bahwa studi kasus memiliki karakteristik penelitian kualitatif dimana adanya latar ilmiah yang menyertainya.

\section{Kerangka Pemikiran}

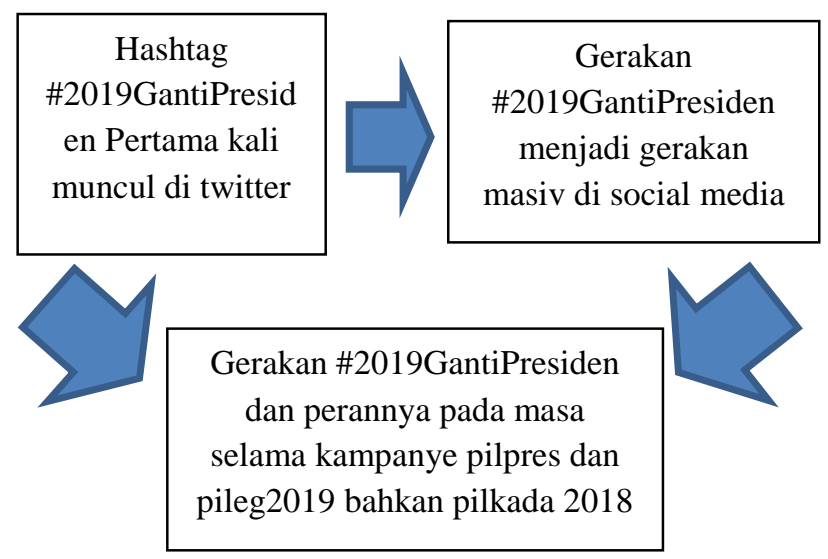

\section{HASIL TEMUAN DAN PEMBAHASAN}

\section{Komunikasi Politik Partai Keadilan Sejahtera}

Komunikasi politik merupakan proses penyampaian pesan-pesan yang terjadi pada saat keenam fungsi lainnya itu dijalankan. Hal ini berarti bahwa fungsi komunikasi politik sangat dekat di dalam setiap fungsi sistem politik.

Gabriel Almond (1960): komunikasi politik adalah salah satu fungsi yang selalu ada dalam setiap sistem politik. "All of the functions performed in the political system, Jakarta.

\footnotetext{
${ }^{7}$ Emzir., 2010, Metodologi Penelitian Pendidikan Kuantitatif dan Kualitatif, Rajawali Pers,
} 
political socialization and recruitment, interest articulation, interest aggregation, rule making, rule application, and rule adjudication, are performed by means of communication." 8

Keunggulan Partai Keadilan Sejahtera (PKS) yang tidak mengandalkan figur atau popularitas kadernya dan mengoptimalkan peran kader akan berpotensi mengantarkannya menjadi partai besar dan modern. Hal ini akan terjadi ketika kelak partai-partai lain kehilangan tokoh, gagal melakukan regenerasi, dan berkutat pada pusaran konflik. Kuncinya PKS mesti menghindari godaan korupsi, konflik internal, dan membumi dengan kemajemukan bangsa. Partai Keadilan Sejahtera selama ini sering memunculkan kader-kader yang mempunyai kemampuan yang dapat membawa perubahan, di beberapa daerah, Partai Keadilan Sejahtera juga berha sil mengusung orang-orangnya menjadi pemimpin di tingkat daerah. ${ }^{9}$

Untuk mencapai target dan merealisasikan target Partai Keadailan Sejahtera melakukan beberapa strateginya seperti yang di utarakan oleh Kang lie Sumirat

"Ya, seiring dengan perubahan zaman dan juga kita sudah mengamati perilaku pemilih dari 3 periode sebelumnya, ini menjadikan PKS juga harus mampu untuk menyesuaikan dirinya dalam menerapkan strategi-strategi yang pas. Paling tidak hal yang utama adalah bagaimana seharusnya kita tetap bertahan menjaga jati diri kita sebagai partai dakwah itu sendiri, yang memberikan banyak manfaat. Yang kedua, juga menghadirkan tokoh-tokoh yang memiliki integritas yang baik. Memang ini sangat penting. Yang ketiga, tahan terhadap ujian, karena diketahui sebelum juga kita PKS menghadapi ujian baik itu ujian dari luar maupun dari dalam. Jadi itu mungkin kolaborasi dari ketiga hal tersebut."

Lebih detail Ust Mardani menyampaikan strategi Partai Keadilan Sejahtera pada saat pemilu legislatif tahun 2019 lalu

"Kalau secara umum kita suka menyebutnya dua hal ya. Serangan darat dan serangan udara. Serangan udara itu message kita apa, key message kita apa, pesan utama, pesan kunci kita apa. itu didefinisikan dengan baik. Kita punya Ayo Lebih Baik lebih baik, karena kita ingin getting better."

Sebagai organisasi politik, partai menginginkan terciptanya citra positif, citra positif dapat ditunjukan melalui penyikapan terhadap peristiwa politik sesuai dengan aspirasi yang sesuai dengan kehendak konstituennya. ${ }^{10}$

\section{Partai Keadilan Sejahtera dan Media Sosial}

Kehadiran media sosial juga mempengaruhi bidang politik. Studi di Amerika Serikat menunjukkan media sosial alat kampanye yang efektif. Sebelum era media sosial, politisi di Negeri Paman Sam sudah memanfaatkan internet untuk media berkampanye. Selain itu media baru mampu untuk menjaring pemilih muda dan biayanya murah

\footnotetext{
${ }^{8}$ Almond, Gabriel A. 1960. The Politics of the Developing Areas. Princeton: Princeton University Press.

${ }_{9}^{9}$ Utomo, S., \& Turtiantoro. (2013). Analisis Kegagalan Partai Keadilan Sejahtera (PKS) dalam Memperebutkan Kurs

${ }^{10}$ Muchtar, K. (2016). Komunikasi Politik dan Pembentukan Citra Partai. Jurnal Ilmu
} 
("Aktor Politik Wajib Manfaatkan Media Sosial", ugm.ac.id, 7 Juni 2013). Pengaruh media sosial dalam dunia politik khususnya dalam hal komunikasi politik, terutama dalam kampanye Pemilu (Chavez, 2012; Riaz, 2010; Stietglitz \& Dang-Xuan, 2012). Penting bagi institusi politik untuk berpartisipasi aktif dalam komunikasi politik yang berbasiskan media sosial, terutama dalam kampanye Pemilu. Media sosial selanjutnya menggambarkan sebagai sarana ideal dan basis informasi untuk mengetahui opini publik tentang kebijakan dan posisi politik, selain untuk membangun dukungan komunitas kepada politisi yang tengah berkampanye.

Partai Keadilan Sejahtera tidak bisa lepas dari memanfaatkan media sosial sebagai sarana kampanye yang efektif, Kang Iie Sumirat menjelaskan bahwa sosial media menjadi salah satu sarana yang digunakan untuk menyampaikan gagasan atau tema kampanye Partai Keadilan Sejahtera. “Jadi memang, pemantauan dari sosial media ini kan salah satu strategi kita dari beberapa strategi. Yang tadi saya jelaskan di awal, PKS memiliki strategi untuk penguatan teritorialnya melalui kerja-kerja kader, seluruh kader, pengurus, maupun simpatisan, dan juga caleg."

\section{Kondisi Perpolitikan Indonesia Jelang Pemilu Presiden}

Tahun 2018 adalah tahun di mulainya tahun politik, kondisi dan situasi perpolitikan di Indonesia makin naik tensinya pasca PILKADA DKI Jakarta tahun 2017 yang pada saat itu telah menjadikan dua kubu yang saling berseberangan dengan begitu kuat dan kentalnya perbedaan yang terjadi. Kubu petahana Ahok-Jarot versus kubu Anies-Sandi, dua pasang kandidat yang menjadi simbol perbedaan pilihan bahkan idiologis. Pertarungan dua kubu ini disebut sebut pertarungan yang emosional kerap menghasilkan isu-isu yang ramai mengundang perbincangan di dunia maya dan juga warung-warung kopi. Isu yang kuat muncul kepermukaan adalah politik indentitas peristiwa fenomenal aksi 212 tidak serta merta bisa dipisahkan dari perkembangan hangatnya dan kentalnya tensi politik di Indonesia. "Politik identitas hampir selalu mewarnai setiap proses pemilu di banyak tempat. Ini terjadi karena identitas adalah salah satu modal penting bagi kandidat/partai untuk memobilisasi dukungan," tutur pakar politik UGM Nanang Indra Kurniawan dalam perbincangan dengan detikcom, Rabu (6/6/2018). ${ }^{11}$

Hal-hal inilah yang menjadikan tahun 2018 kian meningkat suhu politiknnya terlebih lagi pada tahun ini gerakan tagar \#2019GantiPresiden lahir, gerakan yang di inisiasi oleh Dr. Mardani ALi Sera pada saat menjadi nara sumber di ILC Selasa, 27 Februari 2018 dengan mengatakan bahwa "Pak Jokowi dapat di kalahkan". Pernyataan Dr. Mardani Ali Sera inilah yang kemudian menjadi tagar \#2019GantiPresiden kemudian para pengguna twitter yang juga akrab disebut warganet/netizen membicarakan tagar \#2019GantiPresiden yang menjadi Tranding Topic atau sesuatu yang paling ramai

\footnotetext{
${ }^{11}$ https://news.detik.com/berita/d-4056085/jelang-pilpres-2019-akankah-indonesia-terjebakpolitik-identitas
} 


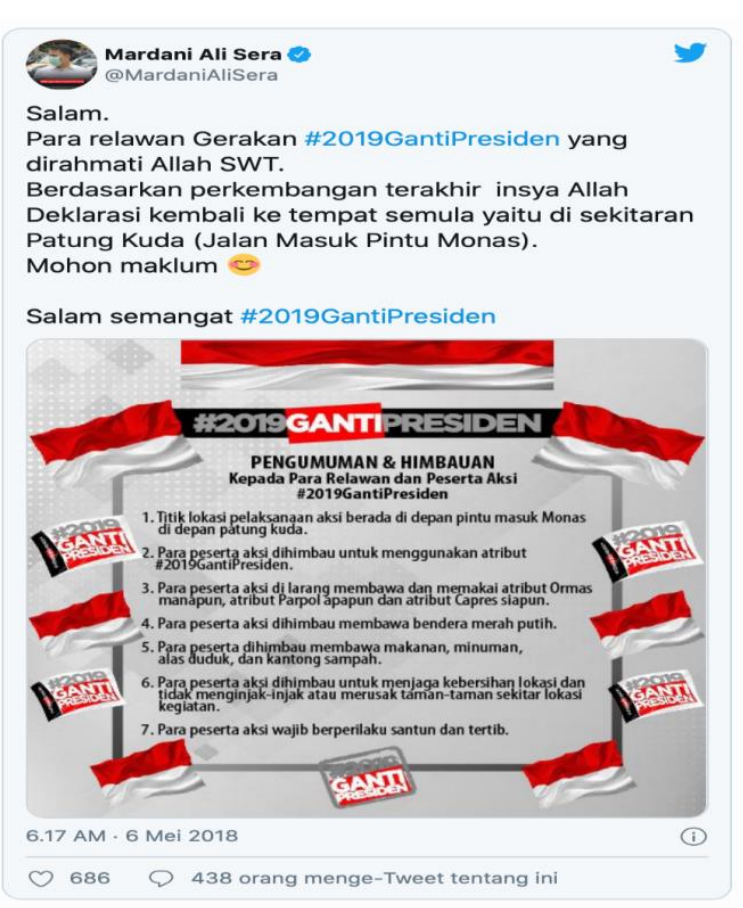

dibicarakan. Tagar itu pertama kali digagas @MardaniAliSera, akun twitter milik politikus PKS (Partai Keadilan Sejahtera) Dr. Mardani Ali Sera beserta kelompoknya (Hadi, Siaful. Tempo. 2018). ${ }^{12}$ Drone Emprit, peranti lunak analisis percakapan di media sosial mengatakan sejak tagar tersebut dibuat mulai 1 April sampai 10 April 2018. Drone Emprit mencatat terdapat 110 ribu mention tentang tagar \#2019GantiPresiden. Bahkan reaksi masyarakat di media sosial membuat tagar tersebut mengalami peningkatan hingga 300 persen pada 8 April 2018, yakni dari 7 ribu mention perhari menjadi 37 ribu perhari (Vivanews.co.id. 2018). ${ }^{13}$

Gambar Twit akun@MardaniAliSera

\section{Lahirnya Gerakan \#2019GantiPresiden}

Gerakan bertagar \#2019GantiPresiden telah memicu banyak perbincangan di media sosial sejak pertama kali digagas oleh politikus PKS Mardani Sera bulan lalu. Gerakan ini kini membentuk kelompok dan akan mendeklarasikan diri hari ini, Ahad, 6 Mei 2018. Sebagai penggagas, Mardani mengatakan gerakan ini diusung untuk mendidik masyarakat dalam berpolitik serta antitesis dari gerakan yang sudah bergulir yaitu 'Dua Periode'. "Gerakan \#2019GantiPresiden akan memberikan data, analisa untuk menyodorkan calon lain yang lebih baik agar dipilih pada Pilpres 2019," kata Mardani, Rabu, 4 April lalu. Pembentukan gerakan \#2019GantiPresiden berawal saat Mardani diundang acara debat di salah satu stasiun TV swasta pada 27 Februari 2018. Selain Mardani, ada beberapa politikus lain yang turut diundang dalam acara itu. (Tempo.co, Minggu/6/Mei/2018) ${ }^{14}$

\section{Afiliasi Gerakan \#2019GantiPresiden dengan Salah Satu Kandidat Capres}

Munculnya gerakan \#2019GantiPresiden jelang dilaksanakan PEMILU Presiden Indonesia dan hanya ada dua kandidat pasangan Capres Cawapres sudah

\footnotetext{
${ }^{12}$ https://nasional.tempo.co/read/1086128/deklarasi-hari-ini-begini-awal-mula-gerakan2019gantipresiden

${ }^{13}$ https://nasional.tempo.co/read/1086128/deklarasi-hari-ini-begini-awal-mula-gerakan2019gantipresiden

${ }^{14}$ https://nasional.tempo.co/read/1086128/deklarasi-hari-ini-begini-awal-mula-gerakan2019gantipresiden
} 
menjadi pilihan yang secara automatis bahwa para aktivis gerakan \#2019GantiPresiden berada pada kubu penantang petahana sudah barang tentu berada pada kubu Prabowo-Sandi hal ini secara tersirat disampaikan oleh pencetus sekaligus deklarator gerakan \#2019GantiPreiden pada media "Menurut Mardani, masih ada waktu kampanye sekitar tujuh bulan hingga pilpres mendatang. Dia pun optimistis massa \#2019GantiPresiden dapat menyumbang suara besar untuk pasangan yang diusung Partai Gerindra, PKS, Partai Amanat Nasional, dan Partai Demokrat ini." (Tempo.co 4/9/18) ${ }^{15}$

\section{Poltical Branding \#2019GantiPresiden}

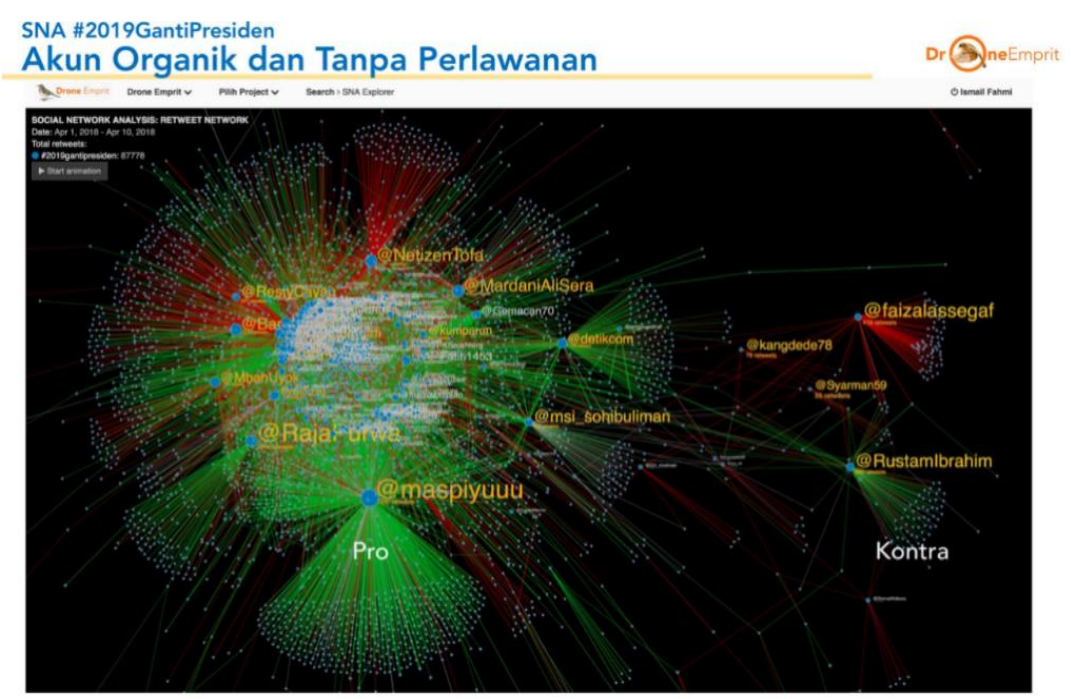

Menurut Scammel sebagaimana dikutip oleh Soetomo (2013:58), branding adalah penggunaan langkah strategis dalam seni membangun citra politik. Hal ini mengacu pada taktik yang digunakan politisi untuk mendapatkan popularitas dan pemilihan.

Kotler (2002) mengemukakan bahwa, brand merupakan nama atau simbol yang bersifat membedakan, dengan maksud mengidentifikasi barang atau jasa dari seorang penjual atau sekelompok penjual tertentu. Brand adalah sesuatu yang tidak terlihat (intangible), tetapi efeknya sangat nyata. ${ }^{16}$

Lorann Downer (2013: 4) mendefinisikan political branding sebagai strategi yang dipilih secara sadar untuk mengidentifikasi dan membedakan serta mempengaruhi penawaran-penawaran politik dengan nilai-nilai emosional maupun fungsional untuk meningkatkan daya tarik dan keterikatan pemilih. ${ }^{17}$

Sebagai political branding tagar \#2019GantiPresiden berhasil menjadi yang terpopuler di Indonesia hal ini terkonfirmasi oleh Lembaga survei Charta Politika melakukan survei soal tagar dari dua pasangan calon capres-cawapres. Hasilnya, tagar

\footnotetext{
${ }^{15}$ https://pilpres.tempo.co/read/1123488/gerakan-2019gantipresiden-ajukan-kontrak-politikuntuk-prabowo/full\&view $=$ ok

${ }^{16}$ Kotler, P. (2002). Manajemen Pemasaran,Edisi Milenium. (2002). Jakarta: PT.Prehalindo.

${ }^{17}$ Downer, L. (2013). Political Branding in Australia: a Conceptual Model. 63rd Political Studies Association Annual International Conference. Cardiff: Political Studies Association.
} 
\#2019GantiPresiden lebih populer dibanding tagar 01 Jokowi Lagi. "Kalau kita lihat seberapa besar sih penetrasi 2019 Ganti Presiden? Yang mengetahui 75 persen, yang setuju 44,1 persen, yang tidak setuju 41,4 persen. Jadi ini angka dari keseluruhan 75 persen," kata Direktur Eksekutif Charta Politika Yunarto Wijaya di Kantor Charta Politika di Kebayoran Baru, Jakarta Selatan, Rabu (16/1/2018) detiknews. ${ }^{18}$

Lansiran viva.co.id (Rabu, 11 April 2018) dengan judul \#2019GantiPresiden Kalahkan \#Jokowi2Periode Berdasarkan data Drone Emprit, peranti lunak analisis percakapan di media online dan media sosial besutan Ismail Fahmi, muncul beberapa fakta dalam perang dua hashtag tersebut. Dalam postingannya di akun Facebook, Ismail menuliskan, Drone Emprit menganalisis data sejak 1 April sampai 10 April. Selama periode tersebut, piranti lunak tersebut mendapatkan, ada 110 ribu mention tentang hashtag \#2019GantiPresiden dan hanya 18 ribu mention untuk \#Jokowi2Periode. ${ }^{19}$

Pada kesempatan lain pencetus tagar \#2019GantiPresiden, Mardani Ali Sera mengatakan pada media yang di kutip oleh Teropong Senayan: "Hasil kajian kami reach di socmed \#2019GantiPresiden sudah mencapai 186 juta.Jangan remehkan kaus,semua dimulai dengan yang kecil. Dulu ada perubahan sosial dimulai dengan bunga. Dengan slogan salam dua jari dan lain-lain. (Ini) Akan jadi bola salju kalau pemerintah terus mengecewakan publik," kata Mardani, Jakarta, Minggu (15/4/2018). ${ }^{20}$

Populernya branding tagar \#2019GantiPresiden membuat incumben Joko Widodo terpancing mengeluarkan statemennya "Sekarang isu kaus ganti presiden 2019. "Masa dengan kaos bisa ganti presiden," kata Jokowi saat memberikan sambutan dalam acara Konvensi Nasional Galang Kemajuan Tahun 2018 di Ballroom Puri Begawan, Bogor, Sabtu (7 April 2018)/liputan6.com 8 April 2018. ${ }^{21}$

Pengukuran Drone Emprit menunjukkan, justru Jokowi merupakan top promotor hashtag tersebut. Gara-garanya adalah komentar Jokowi pada 1 April 2018. Dalam sebuah pidato, Jokowi menyindir gerakan \#2019GantiPresiden, yang membagikan kaos, gelang dengan hashtag tersebut. Jokowi menyangsikan kaos bisa mengganti presiden. "Masa kaos bisa ganti presiden?". Dari grafik tren, Ismail menunjukkan, komentar Jokowi atas \#2019GantiPresiden yang diberitakan media itu memicu naiknya hashtag tersebut. Ismail menuliskan, dari tren volume percakapan, sehari setelah komentar Jokowi itu, total mention harian hashtag \#2019GantiPresiden melonjak tinggi, yakni 300 persen. "Sebelumnya maksimal 7 ribu per hari, menjadi 37 ribu pada tanggal 8 April," tulis Ismail.22

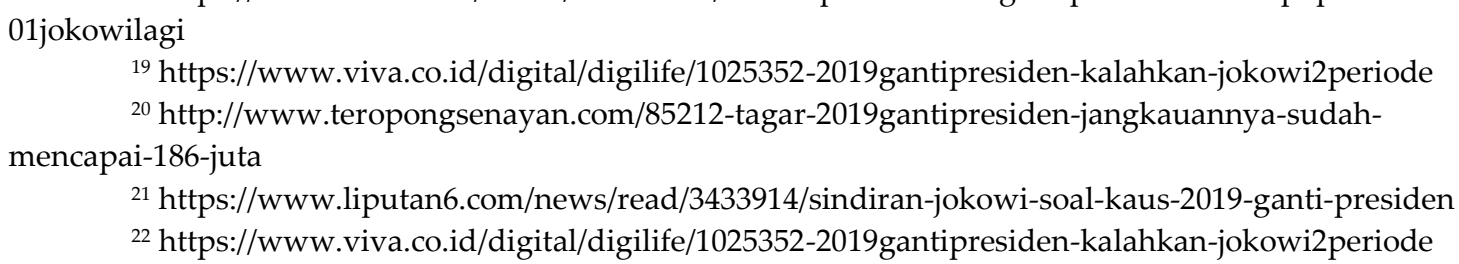

${ }^{19}$ https://www.viva.co.id/digital/digilife/1025352-2019gantipresiden-kalahkan-jokowi2periode

${ }^{20} \mathrm{http}$ ///www.teropongsenayan.com/85212-tagar-2019gantipresiden-jangkauannya-sudahmencapai-186-juta

${ }^{21}$ https://www.liputan6.com/news/read/3433914/sindiran-jokowi-soal-kaus-2019-ganti-presiden

22 https://www.viva.co.id/digital/digilife/1025352-2019gantipresiden-kalahkan-jokowi2periode

${ }^{18}$ https://news.detik.com/berita/d-4387620/charta-politika-2019gantipresiden-lebih-populer-dari- 


\section{Elektabilitas Partai Keadilan Sejahtera di Ranah Media Sosial}

Pengamat politik dari Universitas Pelita Harapan Emrus Sihombing mengatakan pemanfaatan media sosial (medsos) sebagai alat kampanye merupakan suatu bentuk revolusi komunikasi di ranah politik Indonesia. "Tidak dipungkiri, peran medsos berhasil meningkatkan elektabilitas sejumlah partai politik (parpol)," kata Emrus Sihombing di Jakarta, Senin (3/6). ${ }^{23}$

Douglas Hagar (2014) dalam Campaigning Online: Social Media in the 2010 Niagara Municipal Elections menuturkan, media sosial bisa berkontribusi pada keberhasilan politik..$^{24}$

Partai Keadilan Sejahtera mampu "menguasai" jagat digital hal ini juga terjadi ketika tagar \#2019GantiPresiden menjadi trending topik di media sosial khususnya Twitter, "Temuan kami di survei kami dan dianalisis medsos kami, ditemukan generasi milenial yang sehari-hari gunakan medsos lebih memilih tagar 2019GantiPresiden 257 juta itu, jangkauannya mendukung lebih banyak ke tagar \#2019GantiPresiden daripada tagar \#2019TetapJokowi maupun tagar \#JokowiDuaPeriode hanya 159 juta," kata Ketua DPP PKS Bidang Politik Pipin Sopian. ${ }^{25}$

Hal inipun terkonfirmasi oleh hasil survei LSI, Peneliti Lingkaran Survei Indonesia (LSI) Denny JA, Adjie Alfaraby menilai gerakan tagar \#2019GantiPresiden membawa keuntungan tersendiri bagi Partai Keadilan Sejahtera (PKS). Sebab, gerakan yang dipelopori oleh kader PKS Mardani Ali Sera ini bisa meningkatkan elektabilitas PKS di Pemilu 2019. "Menurut saya, kader PKS maupun simpatisan teredukasi dengan tagar \#2019GantiPresiden. Saya bilang itu adalah menguntungkan PKS karena (gerakan) itu diasosiasikan oleh PKS," kata Adjie di kantor LSI Denny JA, Jakarta, Rabu (12/9/2018). Adjie memaparkan, setiap pemilih yang tak ingin memilih calon presiden Joko Widodo akan terpengaruh dengan tagar tersebut dan memilih partai yang tidak mengusung Jokowi, khususnya PKS. "Ketika tagar itu muncul, maka itu sebetulnya menguntungkan PKS," paparnya. Ia juga menuturkan, meskipun tagar \#2019GantiPresiden diubah menjadi \#2019PrabowoPresiden, tagar baru itu tetap mencerminkan gerakan mengganti kepemimpinan nasional dan tetap terasosiasikan dengan PKS. "Menurut saya imagenya tetap sama. Ini kan langkah karena masa kampanye, jadi ganti Presiden adalah Prabowo (jadi) Presiden. Jadi tetap menguntungkan PKS," ujarnya. ${ }^{26}$

Kuatnya tagar \#2019GantiPresiden di media sosial menjadikan Partai Keadilan Sejahtera populer serta meningkatkan elektabilitas Partai Keadilan Sejahtera di ranah media sosial, sudah bukan rahasia lagi bahwa tagar \#2019GantiPresiden adalah terasosiasikan kepada Partai Keadilan Sejahtera karena yang mencetuskan tagar \#2019GantiPresiden adalah kader Partai Keadilan Sejahtera sendiri yaitu Dr. Mardani Ali Sera hal ini terkonfirmasi oleh Presiden Partai Keadilan Sejahtera (PKS) Dr.

${ }^{23}$ https://republika.co.id/berita/psj0c2428/pengamat-media-sosial-tingkatkan-elektabilitas-parpol

${ }^{24}$ Hagar, D. (2014). Campaigning Online: Social Media in the 2010 Niagara Municipal Elections.Canadian Journal of Urban Research 23 (1), pp. 74-98

${ }^{25}$ https://news.detik.com/berita/d-4212972/pks-di-medsos-milenial-lebih-suka-2019gantipresiden

${ }^{26} \mathrm{https} / /$ nasional.republika.co.id/berita/nasional/politik/18/09/12/pexxdh409-lsi-gerakan2019gantipresiden-untungkan-pks-tapi 
Muhammad Shohubul Iman seperti yang diliput oleh tirto.id 9 April 2019 di Jakarta, Presiden Partai Keadilan Sejahtera (PKS), Sohibul Iman mengklaim tagar 2019GantiPresiden kini telah menjadi gerakan spontan masyarakat yang menghendaki perubahan.

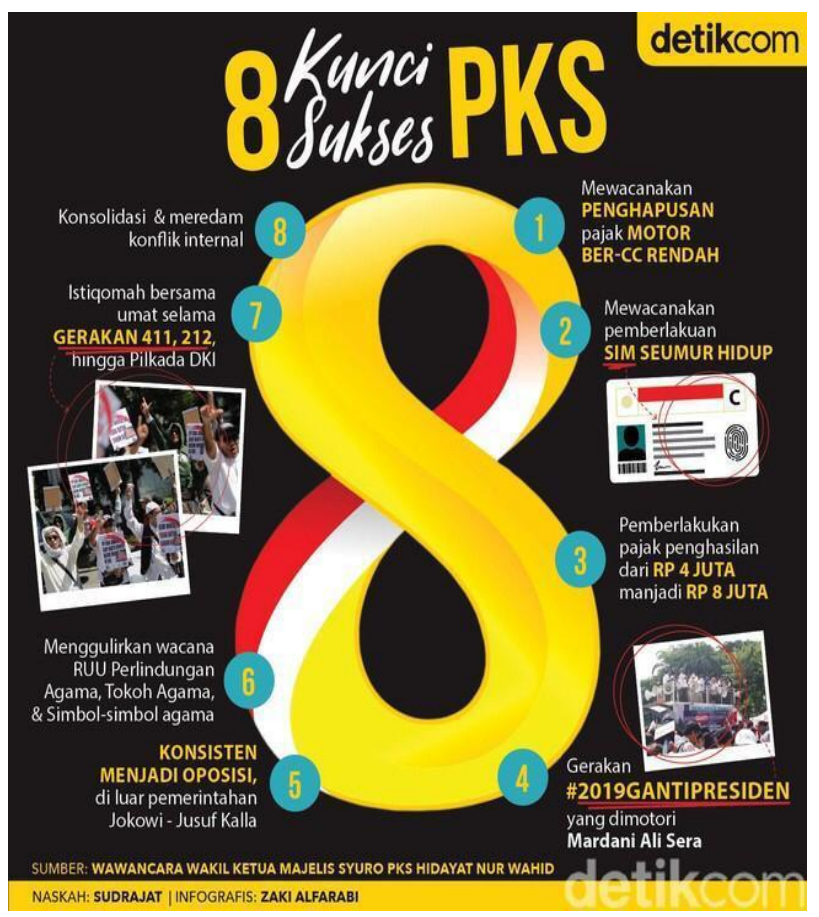

Sohibul menambahkan, ide gerakan itu berasal dari Ketua DPP PKS, Mardani Ali Sera. Menurut dia, Mardani mengawali gerakan itu sebab berharap ada presiden baru selain Joko Widodo usai Pilpres 2019. "Memang yang pertama mencetuskan adalah saudara Mardani Ali Sera, itu iya. Tapi itu sekarang sudah menjadi gerakan seluruh masyarakat yang menginginkan perubahan," kata Sohibul. ${ }^{27}$

Digdayanya tagar \#2019GantiPresiden membuat Partai Keadilan Sejahtera yang mendapatkan "keberkahan" dari tagar \#2019GantiPresiden seperti yang dilansir media "Mardani pun tak dapat memungkiri, pengaruh gerakan 212 hingga narasi \#2019GantiPresiden turut menjadi faktor penentu melejitnya suara PKS, dalam pesta demokrasi 5 tahunan." (Tagar.id 24 April 2019). ${ }^{28}$

"Selain karena program, menurut dia (Mardani), suara PKS juga bisa bertambah karena kinerja caleg dan seluruh kader dan simpatisan yang militan. Menurut dia seluruh kader bekerja keras selama masa kampanye. Faktor lain, ada juga pengaruh gerakan alumni 212 hingga gerakan \#2019GantiPresiden." (Kompas, 18 April 2019). ${ }^{29}$

Dalam sebuah info grafis detik.com membuat delapan kunci PKS yang salah satunya adalah tagar \#2019GantiPresiden. (Detik.com, 29 Juli 2019) Dengan demikian dapat dibuktikan bahwa political branding tagar \#2019GantiPresiden memiliki

\footnotetext{
${ }^{27}$ https://tirto.id/presiden-pks-mardani-ali-sera-pencetus-gerakan-2019gantipresiden-cHus

${ }^{28} \mathrm{https} / /$ www.tagar.id/pks-diprediksi-gurem-malah-melejit-di-pemilu-2019

${ }^{29}$ https://nasional.kompas.com/read/2019/04/18/14470911/suaranya-naik-dalam-quick-count-pksmerasa-bukan-karena-prabowo-sandi
} 
kontribusi bukan saja elektabilitas di ranah media sosial tetapi juga pada elektoral Partai Keadilan Sejahtera pada saat pemilu legislatif tahun 2019 lalu.

\section{KESIMPULAN}

Pentingnya branding politik bagi partai politik yang utamanya mengikuti kontestasi lima tahunan dalam sistem pemilu di Indonesia untuk meningkatkan popularitas dan elektabilitas. Partai politik yang modern harus bisa menggarap dengan serius branding politiknya agar mampu dan di terima oleh segmen atau target yang akan diambilnya. Hal-hal terkait yang perlu ditindaklanjuti adalah sebagai berikut:

1. Memastikan branding politik sesuai dengan apa yang akan di targetkan untuk itu perlu diadakan survey publik hal apa yang menjadi concern masyarakat pada saat ini, branding politik yang sesuai dengan suasana kebatinan masyarakat pada umunya

2. Memastikan media sosial menjadi media utama untuk penyebaran dan kampanye branding politik, karena media sosial murah dan efektif serta mampu menyasar pada target yang di sasara atau yang di tuju

3. Penggunaan tanda pagar (tagar) yang relevan dengan branding politik yang akan di munculkan ke permukaan hal ini perlu dilakukan agar menjadi trending di media sosial, bila menjadi trending maka dengan sendiri biaya kampanye atau sosialisasi akan jauh lebih murah

4. Atribusi branding politik harus in line dengan aktivitas kampanye di dunia maya dan dunia nyata (darat)

\section{REFERENSI:}

Almond, Gabriel A. 1960. The Politics of the Developing Areas. Princeton: Princeton University Press.

Deddy Mulyana, Metodologi Penelitian Kualitatif. (Bandung: PT Remaja Rosdakarya, 2006)

Downer, L. (2013). Political Branding in Australia: a Conceptual Model. 63rd Political Studies Association Annual International Conference. Cardiff: Political Studies Association.

Emzir., 2010, Metodologi Penelitian Pendidikan Kuantitatif dan Kualitatif, Rajawali Pers, Jakarta.

Hagar, D. (2014). Campaigning Online: Social Media in the 2010 Niagara Municipal Elections.Canadian Journal of Urban Research 23 (1), pp. 74-98

Kotler, P. (2002). Manajemen Pemasaran,Edisi Milenium. (2002). Jakarta: PT.Prehalindo.

Muchtar, K. (2016). Komunikasi Politik dan Pembentukan Citra Partai. Jurnal Ilmu 
Nur Rohim, "Gagasan Pemilukada Serentak dan Implikasinya Terhadap Pesta Demokrasi yang Efektif dan Efisien," Jurnal Nanggroe, Volume 3, No. 3 (2016).

Patton, Micheal Quinn. 2002. Qualitative Research and Evaluation Methods. USA: Sage Publication, Inc

Soetomo. Personal Branding Dalam Peningkatan Elektabilitas. Magister Ilmu Komunikasi Undip, Praktisi Fotografi dalam Jurnal Ilmiah Komunikasi "MAKNA" Fakultas Ilmu Komunikasi UNISSULA Semarang, volume 4 nomor 1, Februari-Juli 2013.

Susilowati, I; Yunus, NR; Sholeh, M. "Politics of identity on great 212's reunion", Dauliyah Journal of Islamic and International Affairs 4 (1), 58-79.

Towner, Terri L. (2013). All Political Participation Is Socially Networked? New Media and the 2012 Election. Social Science Computer Review

Utomo, Dea Anggraeni. (2013). Motif Pengguna Jejaring Sosial Google+ di Indonesia dalam Jurnal E-Komunikasi Prodi Ilmu Komunikasi Universitas Kristen Petra Surabaya, Vol. 1, No. 3 : Surabaya.

Utomo, S., \& Turtiantoro. (2013). Analisis Kegagalan Partai Keadilan Sejahtera (PKS) dalam Memperebutkan Kurs

https://nasional.kompas.com/read/2018/09/12/21145981/peneliti-lsi-gerakan2019gantipresiden-berpotensi-untungkan-pks-di-pemilu

https://nasional.republika.co.id/berita/nasional/pilkada/pb87ny354/dedi-mulyadi-nilaitagar-2019gantipresiden-gerus-suaranya

https://news.detik.com/berita/d-4387620/charta-politika-2019gantipresiden-lebihpopuler-dari-01jokowilagi

https://www.academia.edu/5512344/Pengertian Komunikasi Politik

https://www.kanigoro.com/artikel/mengenal-teori-branding-politik/

https://irto.id/perang-di-media-sosial-untuk-merebut-jakarta-b44r

https://nasional.republika.co.id/berita/nasional/pilkada/pb87ny354/dedi-mulyadi-nilaitagar-2019gantipresiden-gerus-suaranya

https://nasional.kompas.com/read/2018/09/12/21145981/peneliti-lsi-gerakan2019gantipresiden-berpotensi-untungkan-pks-di-pemilu

https://tirto.id/presiden-pks-mardani-ali-sera-pencetus-gerakan-2019gantipresiden$\underline{\mathrm{cHus}}$

https://news.detik.com/berita/d-4056085/jelang-pilpres-2019-akankah-indonesiaterjebak-politik-identitas

https://news.detik.com/kolom/d-4030659/meredam-polarisasi-pilpres-2019

http://seriau.com/news/detail/17024/politik-pemerintahan/3-alasan-pks-yakin-jokowidapat-dikalahkan-di-pilpres-2019 
https://nasional.tempo.co/read/1086128/deklarasi-hari-ini-begini-awal-mula-gerakan2019gantipresiden/full\&view $=$ ok

https://www.inews.id/news/nasional/dipimpin-mardani-ini-deklarasi-gerakan2019gantipresiden

http://www.teropongsenayan.com/85212-tagar-2019gantipresiden-jangkauannyasudah-mencapai-186-juta

https://www.tagar.id/pks-diprediksi-gurem-malah-melejit-di-pemilu-2019 